\title{
The Situation of Management Research in Peru. A Bibliometric Analysis in the Bicentennial
}

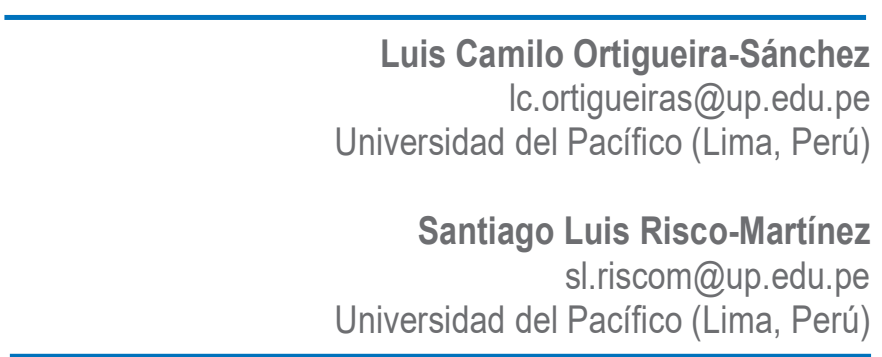

\begin{abstract}
In 2021, Peru celebrated 200 years of independence, marking an important milestone in its history, which leads us to the following question: In these 200 years, how much progress has been made in business studies in Peru? We found bibliometric analysis to be the most appropriate method to answer this question. The software used to analyze the interrelationships between articles was Vosviewer, a software that allows the creation and visualization of bibliometric networks. Using the search terms "Peru" and "Business", we retrieved 908 articles from the Scopus Database.
\end{abstract}

Keywords: Bibliometric Analysis, Business, Peru, Scopus, Vosviewer 


\title{
La Situación de la Investigación Gerencial en el Perú. Un análisis bibliométrico en el Bicentenario
}

$\begin{array}{r}\text { Luis Camilo Ortigueira-Sánchez } \\ \text { Ic.ortigueiras@up.edu.pe }\end{array}$
Universidad del Pacífico (Lima, Perú)
Santiago Luis Risco-Martínez
sl.riscom@up.edu.pe
Universidad del Pacífico (Lima, Perú)

\begin{abstract}
En el 2021, el Perú cumplió 200 años de independencia, marcando un hito importante en su historia, lo que nos lleva a la siguiente pregunta: En estos 200 años, ¿cuánto se ha avanzado en los estudios empresariales en el Perú? Encontramos que el análisis bibliométrico es el método más apropiado para responder a esta pregunta. El software utilizado para analizar las interrelaciones entre artículos fue Vosviewer, un software que permite la creación y visualización de redes bibliométricas. Utilizando los términos de búsqueda "Perú" y "Negocios", se procesaron 908 artículos encontrados en la base de datos Scopus.
\end{abstract}

Palabras clave: Análisis bibliométrico, Negocios, Peru, Scopus, Vosviewer 


\section{Introduction}

Business and management studies in South American countries are a topic of wide interest in the academic world. Studying how these countries have evolved in knowledge development, how they compare with first world countries, is a valuable source of information for future research. In 2021, Peru celebrated 200 years of independence, marking an important milestone in its history, which leads us to the following question: In these 200 years, how much progress has been made in business studies in Peru? We believe that answering this question is relevant to explore the current level of research on Peru and business. We found a bibliometric analysis to be the most appropriate method for this purpose.

These studies use a variety of bibliometric data to get a general idea of the current level of research on a specific topic. This type of studies is popular in the scientific world, and can be found applied into different topics such as social sciences, psychology, economics, business, entrepreneurship, among others (Pineda Escobar \& Merigó, 2020). One of the most popular bibliometric data for this type of studies is the data on citations and references of scientific articles.

The use of citation analysis allows a quantitative study to be made of bibliometric data related to citations of scientific articles. These data, such as, for example, the number of times scientific research or an author is cited, or the number of documents published by a researcher or scientific journal, allows to have impact or quality measures of various agents in the research field (Moed, 2019). This is why scientific research indexed in the most recognized databases, such as Web of Science or Scopus, are usually the main object of study in this type of research. In addition, these databases allow downloading the metadata of these articles containing the bibliometric information required for the study.

A bibliometric study of articles on business and Peru would show the level of studies on these topics. This will allow us to observe which are the countries with the highest production in these topics, as well as which are the most popular authors or scientific journals. Furthermore, it will be possible to observe if there are co-citation networks between researchers or countries. It is even possible to find the existence of research clusters between authors, topics, countries, scientific journals, etc.

The following sections are: the theoretical framework, which highlights the importance of studies on Peru and business; the methodology, where a description of the sample collection and the software used (Vosviewer) is made; the results, where we describe the results along with the tables and figures generated in Vosviewer; and finally, the conclusions of the study.

\section{Methodology}

The data used in this study were obtained from the Scopus database. The search terms used were "Peru" and "Business". A total of 924 articles were found in the database that met the search requirements. Articles that were in press and those from the year 2022 onwards were eliminated, leaving a total of 908 articles. Since Perú was written as "Peru" in some articles and as "Perú" in others, they were all standardized to "Peru". The metadata of these articles were exported to be used with the Vosviewer software. 
The software used to analyze the interrelationships between articles was Vosviewer, a tool that allows the creation and visualization of bibliometric networks (van Eck \& Waltman, 2010) and that has been used in other studies to perform bibliometric studies on business topics or journals (Dubois \& Walsh, 2017; Maia \& Di serio, 2017; Ferreira et al., 2017).

Vosviewer allows you to build networks consisting of items that can represent scientific articles, journals, researchers, research institutions, countries, or keywords. These items are connected by relationships representing levels of co-authorship, co-occurrence, citation, bibliographic matching, or co-citation. Vosviewer also allows you to view other data such as the number of documents published by authors, journals or countries, as well as the number of times they have been cited.

The Vosviewer software provides definitions of the 5 possible types of analysis for bibliometric analysis. Co-authorship, where the relationship of items depends on the number of documents co-authored. Co-occurrence, where the relationship of items depends on the number of documents in which they appear together. Citation, where the relationship of items depends on the number of times they cite each other. Bibliographic matching, where the relationship of items depends on the number of references they share. And co-citation, where the relationship of items depends on the number of times they have been cited together.

For purposes of this research, we analyzed co-authorship between countries, cooccurrence between keywords proposed by researchers, citation between countries, bibliographic matching of countries, and co-citation of scientific journals and researchers. All analyses were performed with the default values of Vosviewer except for journal cocitation, where the minimum number of citations was doubled to 40 , in order to facilitate interpretation of the data. For co-citation by authors, only the 40 authors with the highest degree of co-citation are shown.

\section{Results}

Results of the 6 analyses are presented in tables 1 to 6 . These show the items of each analysis, whether they are countries, keywords, scientific journals or researchers. Countries are indicated by the number of documents and citations attributed to them and the ratio of citations per document. Keywords defined by authors are shown with the number of occurrences. Scientific journals are indicated by the number of times they are cited. All items are followed by their total link strength according to the network analysis in Vosviewer. What the total link strength represents depends on the type of analysis performed.

Figures 1 to 6 are the graphical representations of the networks made in Vosviewer. Circles depict the items in the sample; the larger the circle, the greater the total link strength. Lines represent the existence of a relationship between items. The thicker the line, the stronger the relationship between the items. The proximity of the items also represents the strength of their relationship. Colors represent the clustering of the items.

\section{Co-authorship per country}

Co-authorship analysis allows us to see the volume of joint papers in each country. The greater the total link strength, the greater the number of co-authored papers per country. Table 1 shows the levels of co-authorship found in the sample. It is evident that the United States is the country with the highest number of citations, while Peru is the country with the highest number of published papers and has the highest linkage strength. This indicates that Peru has the highest degree of collaborative work with other countries, which is to be expected because one of the search terms for the sample is Peru. In 
addition, it can be seen that the United States is the country with the second highest level of collaborative work when searching for business and Peru. Costa Rica and Uruguay are the countries with the highest number of citations per paper.

Figure 1 is the graphical representation of the co-authorship network made in Vosviewer. Circles depict the countries in the sample. Here, Peru and the United States show the highest total link strength. An interesting result is that Peru is located in a different cluster than most Latin American countries and the country with the highest number of citations, the United States.

Table 1. Co-authorship per country sorted by number of citations

\begin{tabular}{|c|c|c|c|c|c|}
\hline Rank & Country & Documents & Citations & $\mathrm{C} / \mathrm{D}$ & $\begin{array}{l}\text { Total Link } \\
\text { Strength }\end{array}$ \\
\hline 1 & United States & 246 & 5361 & 21.7926829 & 164 \\
\hline 2 & Peru & 337 & 4024 & 11.9406528 & 301 \\
\hline 3 & $\begin{array}{l}\text { United } \\
\text { Kingdom }\end{array}$ & 90 & 1614 & 17.9333333 & 89 \\
\hline 4 & Canada & 35 & 875 & 25 & 33 \\
\hline 5 & Spain & 79 & 768 & 9.72151899 & 78 \\
\hline 6 & Brazil & 40 & 742 & 18.55 & 60 \\
\hline 7 & Germany & 38 & 700 & 18.4210526 & 37 \\
\hline 8 & Chile & 36 & 655 & 18.1944444 & 53 \\
\hline 9 & Argentina & 26 & 613 & 23.5769231 & 55 \\
\hline 10 & France & 31 & 524 & 16.9032258 & 42 \\
\hline 11 & Colombia & 35 & 502 & 14.3428571 & 67 \\
\hline 12 & Mexico & 26 & 433 & 16.6538462 & 53 \\
\hline 13 & Switzerland & 16 & 361 & 22.5625 & 25 \\
\hline 14 & Australia & 19 & 290 & 15.2631579 & 31 \\
\hline 15 & Italy & 17 & 272 & 16 & 18 \\
\hline 16 & Ecuador & 11 & 196 & 17.8181818 & 18 \\
\hline 17 & Costa Rica & 6 & 186 & 31 & 20 \\
\hline 18 & Uruguay & 6 & 186 & 31 & 25 \\
\hline 19 & Netherlands & 22 & 176 & 8 & 17 \\
\hline 20 & Norway & 6 & 165 & 27.5 & 9 \\
\hline 21 & China & 12 & 163 & 13.5833333 & 11 \\
\hline 22 & Denmark & 7 & 162 & 23.1428571 & 5 \\
\hline 23 & Finland & 10 & 145 & 14.5 & 10 \\
\hline 24 & Japan & 13 & 129 & 9.92307692 & 15 \\
\hline 25 & Bolivia & 8 & 114 & 14.25 & 16 \\
\hline 26 & $\begin{array}{c}\text { Czech } \\
\text { Republic }\end{array}$ & 5 & 113 & 22.6 & 4 \\
\hline 27 & Belgium & 7 & 99 & 14.1428571 & 14 \\
\hline 28 & Austria & 8 & 88 & 11 & 6 \\
\hline 29 & Sweden & 8 & 75 & 9.375 & 14 \\
\hline 30 & India & 5 & 65 & 13 & 10 \\
\hline 31 & Singapore & 5 & 48 & 9.6 & 7 \\
\hline 32 & Indonesia & 5 & 44 & 8.8 & 10 \\
\hline 33 & New Zealand & 7 & 39 & 5.57142857 & 5 \\
\hline
\end{tabular}




\section{Figure 1. Co-authorship network per country}

\section{\& vosviewer}

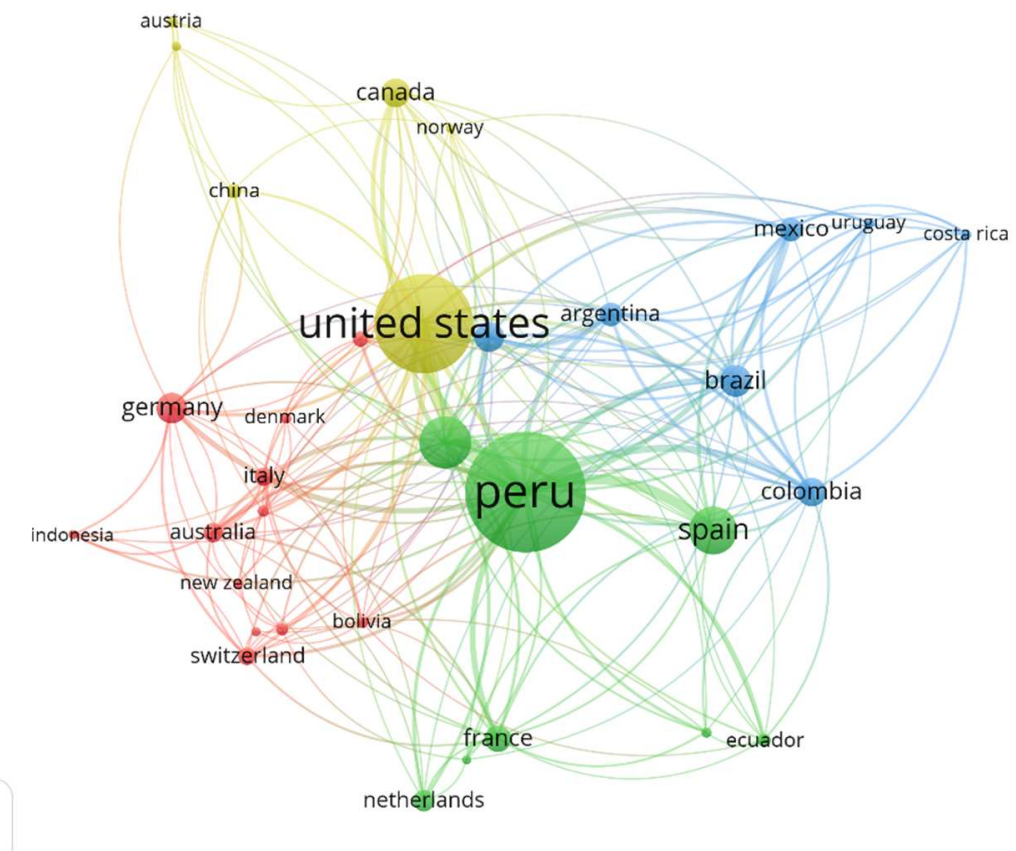

Source: own elaboration

\section{Co-occurrence of keywords by author}

Table 2 shows the result of the keywords co-occurrence analysis per author. This analysis allows us to analyze which are the most popular keywords used by researchers. Given that one of the search criteria was "Peru", it is not surprising that this appears as the most used keyword with the highest level of matching. The most used keyword that does not involve a geographic aspect is "entrepreneurship, and the second most used keyword is "innovation". These results were to be expected since the study of innovation and entrepreneurship in third world countries is a topic of wide interest in the scientific world.

Figure 2 shows the network created in Vosviewer. "Peru" is at the center of the network and is the largest item because it has the largest link strength by a high margin. "Peru" is found in a cluster with terms such as "management", "sustainability", and "sustainable development"; and locations such as "Bolivia", "Brazil", "Ecuador" and "Andes". While "Entrepreneurship" and "Innovation" are clustered with other research topics such as "Competition", "Culture", "Development", "Economic Growth", "Microfinance", "Productivity" and "South America". 
Table 2. Co-occurrence of keywords defined by authors

\begin{tabular}{|c|c|c|c|}
\hline Rank & Keyword & Occurrences & Total Link Strength \\
\hline 1 & Peru & 171 & 142 \\
\hline 2 & Latin America & 41 & 27 \\
\hline 3 & Entrepreneurship & 21 & 16 \\
\hline 4 & Andes & 19 & 21 \\
\hline 5 & Innovation & 17 & 14 \\
\hline 6 & Amazon & 15 & 18 \\
\hline 7 & Sustainable Development & 12 & 15 \\
\hline 8 & Climate Change & 11 & 12 \\
\hline 9 & Bolivia & 10 & 23 \\
\hline 10 & Mining & 10 & 16 \\
\hline 11 & Sustainability & 10 & 10 \\
\hline 12 & Emerging Markets & 9 & 5 \\
\hline 13 & $\begin{array}{c}\text { Corporate Social } \\
\text { Responsibility }\end{array}$ & 8 & 16 \\
\hline 14 & Development & 8 & 13 \\
\hline 15 & Ecuador & 8 & 19 \\
\hline 16 & Microfinance & 8 & 9 \\
\hline 17 & Poverty & 8 & 6 \\
\hline 18 & Argentina & 7 & 11 \\
\hline 19 & Brazil & 7 & 20 \\
\hline 20 & Chile & 7 & 12 \\
\hline 21 & Conservation & 7 & 9 \\
\hline 22 & Culture & 7 & 8 \\
\hline 23 & Deforestation & 6 & 5 \\
\hline 24 & Economic Growth & 6 & 4 \\
\hline 25 & Emerging Economies & 6 & 13 \\
\hline 26 & Gis & 6 & 4 \\
\hline 27 & Hiv & 6 & 5 \\
\hline 28 & Productivity & 6 & 3 \\
\hline 29 & Taxonomy & 6 & 2 \\
\hline 30 & Vulnerability & 6 & 8 \\
\hline 31 & Colombia & 5 & 15 \\
\hline 32 & Competition & 5 & 4 \\
\hline 33 & Developing Countries & 5 & 1 \\
\hline 34 & Distribution & 5 & 4 \\
\hline 35 & Economic Development & 5 & 4 \\
\hline 36 & Gender & 5 & 6 \\
\hline 37 & Genetic Diversity & 5 & 4 \\
\hline 38 & Management & 5 & 4 \\
\hline 39 & Microsatellites & 5 & 3 \\
\hline 40 & Redd + & 5 & 7 \\
\hline 41 & South America & 5 & 2 \\
\hline
\end{tabular}


Figure 2. Co-occurrence network of keywords defined by authors

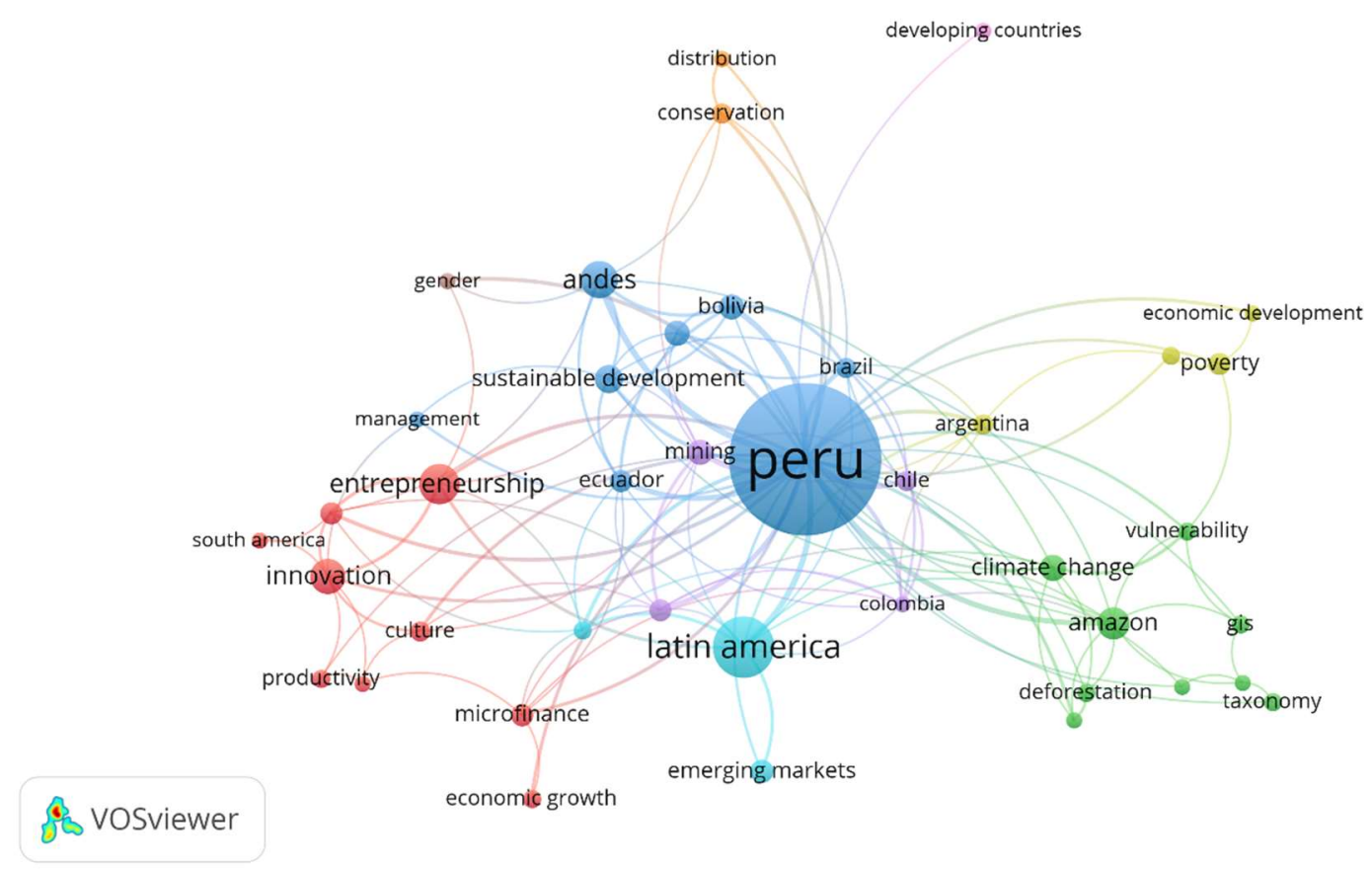

Source: own elaboration

\section{Citation per country}

Table 3 shows the volume of citation links per country. Peru is the country with the most citation links with other countries although the United States is the country with the highest number of citations. This result suggests that Peruvian research tends to cite research works from other countries in greater volume.

Figure 3 shows the graphical representation of the network. Here, Peru, besides being the largest item in the network, is the item with the highest number of links.

Table 3. Citations per country

\begin{tabular}{cccccc}
\hline Rank & Country & Documents & Citations & C/D & $\begin{array}{c}\text { Total Link } \\
\text { Strength }\end{array}$ \\
\hline 1 & Peru & 337 & 4024 & 11.94065282 & 88 \\
2 & United & 246 & 5361 & 21.79268293 & 41 \\
& States & & & & 32 \\
3 & United & 90 & 1614 & 17.93333333 & \\
& Kingdom & & & & 19 \\
4 & Spain & 79 & 768 & 9.721518987 & 11 \\
5 & Brazil & 40 & 742 & 18.55 & 29 \\
6 & Germany & 38 & 700 & 18.42105263 & 9 \\
7 & Chile & 36 & 655 & 18.19444444 & 4 \\
8 & Canada & 35 & 875 & 25 & 9 \\
9 & Colombia & 35 & 502 & 14.34285714 & 4 \\
10 & France & 31 & 524 & 16.90322581 & 0 \\
11 & Argentina & 26 & 613 & 23.57692308 & 9 \\
12 & Mexico & 26 & 433 & 16.65384615 &
\end{tabular}




\begin{tabular}{|c|c|c|c|c|c|}
\hline 13 & Netherlands & 22 & 176 & 8 & 3 \\
\hline 14 & Australia & 19 & 290 & 15.26315789 & 3 \\
\hline 15 & Italy & 17 & 272 & 16 & 2 \\
\hline 16 & Switzerland & 16 & 361 & 22.5625 & 7 \\
\hline 17 & Japan & 13 & 129 & 9.923076923 & 1 \\
\hline 18 & China & 12 & 163 & 13.58333333 & 8 \\
\hline 19 & Ecuador & 11 & 196 & 17.81818182 & 5 \\
\hline 20 & Finland & 10 & 145 & 14.5 & 1 \\
\hline 21 & Bolivia & 8 & 114 & 14.25 & 2 \\
\hline 22 & Austria & 8 & 88 & 11 & 0 \\
\hline 23 & Sweden & 8 & 75 & 9.375 & 2 \\
\hline 24 & Denmark & 7 & 162 & 23.14285714 & 0 \\
\hline 25 & Belgium & 7 & 99 & 14.14285714 & 3 \\
\hline 26 & $\begin{array}{c}\text { New } \\
\text { Zealand }\end{array}$ & 7 & 39 & 5.571428571 & 0 \\
\hline 27 & Costa Rica & 6 & 186 & 31 & 2 \\
\hline 28 & Uruguay & 6 & 186 & 31 & 0 \\
\hline 29 & Norway & 6 & 165 & 27.5 & 0 \\
\hline 30 & $\begin{array}{c}\text { Czech } \\
\text { Republic }\end{array}$ & 5 & 113 & 22.6 & 6 \\
\hline 31 & India & 5 & 65 & 13 & 0 \\
\hline 32 & Singapore & 5 & 48 & 9.6 & 3 \\
\hline 33 & Indonesia & 5 & 44 & 8.8 & 2 \\
\hline
\end{tabular}

Minimum number of documents per country: 5

Source: own elaboration

Figure 3. Citation Network per country

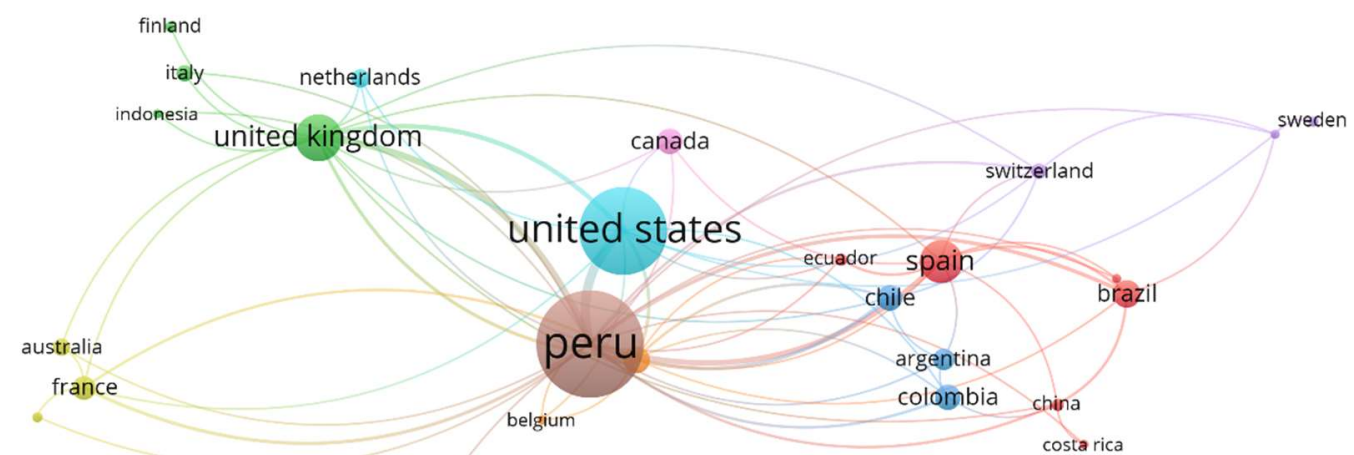

\section{B Vosviewer}

japan

Source: own elaboration 


\section{Bibliographic matching per country}

Table 4 shows the number of references that one country has in common with another. Peru and the United States are the countries with the highest number of references shared with other countries, which is to be expected since both have the largest number of published documents. It is worth noting that out of all the analyses carried out in this research, the bibliographic matching analysis has the highest linkage strength values. This result may be due to the relatively low number of scientific productions meeting the search criteria. It is possible that the low number of researches led to the fact that they share several references.

Table 4. Bibliographic matching per country

\begin{tabular}{|c|c|c|c|c|c|}
\hline Rank & Country & Documents & Citations & $\mathrm{C} / \mathrm{D}$ & Total Link Strength \\
\hline 1 & Peru & 337 & 4024 & 11.9406528 & 18672 \\
\hline 2 & United States & 246 & 5361 & 21.7926829 & 11344 \\
\hline 3 & $\begin{array}{l}\text { United } \\
\text { Kingdom }\end{array}$ & 90 & 1614 & 17.9333333 & 6697 \\
\hline 4 & Spain & 79 & 768 & 9.72151899 & 5163 \\
\hline 5 & Brazil & 40 & 742 & 18.55 & 3922 \\
\hline 6 & Germany & 38 & 700 & 18.4210526 & 2772 \\
\hline 7 & Chile & 36 & 655 & 18.1944444 & 3783 \\
\hline 8 & Canada & 35 & 875 & 25 & 2521 \\
\hline 9 & Colombia & 35 & 502 & 14.3428571 & 4158 \\
\hline 10 & France & 31 & 524 & 16.9032258 & 2098 \\
\hline 11 & Argentina & 26 & 613 & 23.5769231 & 3322 \\
\hline 12 & Mexico & 26 & 433 & 16.6538462 & 3147 \\
\hline 13 & Netherlands & 22 & 176 & 8 & 808 \\
\hline 14 & Australia & 19 & 290 & 15.2631579 & 2128 \\
\hline 15 & Italy & 17 & 272 & 16 & 2586 \\
\hline 16 & Switzerland & 16 & 361 & 22.5625 & 1768 \\
\hline 17 & Japan & 13 & 129 & 9.92307692 & 820 \\
\hline 18 & China & 12 & 163 & 13.5833333 & 1876 \\
\hline 19 & Ecuador & 11 & 196 & 17.8181818 & 1178 \\
\hline 20 & Finland & 10 & 145 & 14.5 & 876 \\
\hline 21 & Austria & 8 & 88 & 11 & 144 \\
\hline 22 & Bolivia & 8 & 114 & 14.25 & 867 \\
\hline 23 & Sweden & 8 & 75 & 9.375 & 2800 \\
\hline 24 & Belgium & 7 & 99 & 14.1428571 & 965 \\
\hline 25 & Denmark & 7 & 162 & 23.1428571 & 417 \\
\hline 26 & New Zealand & 7 & 39 & 5.57142857 & 542 \\
\hline 27 & Costa Rica & 6 & 186 & 31 & 1273 \\
\hline 28 & Norway & 6 & 165 & 27.5 & 752 \\
\hline 29 & Uruguay & 6 & 186 & 31 & 1340 \\
\hline 30 & $\begin{array}{c}\text { Czech } \\
\text { Republic }\end{array}$ & 5 & 113 & 22.6 & 239 \\
\hline 31 & India & 5 & 65 & 13 & 786 \\
\hline 32 & Indonesia & 5 & 44 & 8.8 & 1013 \\
\hline 33 & Singapore & 5 & 48 & 9.6 & 581 \\
\hline
\end{tabular}


Figure 4 is the graphical representation of the network. As it can be seen, the relationship between the items (the curved lines) are much more pronounced in this graph compared to the other ones.

Figure 4. Bibliographic matching per country

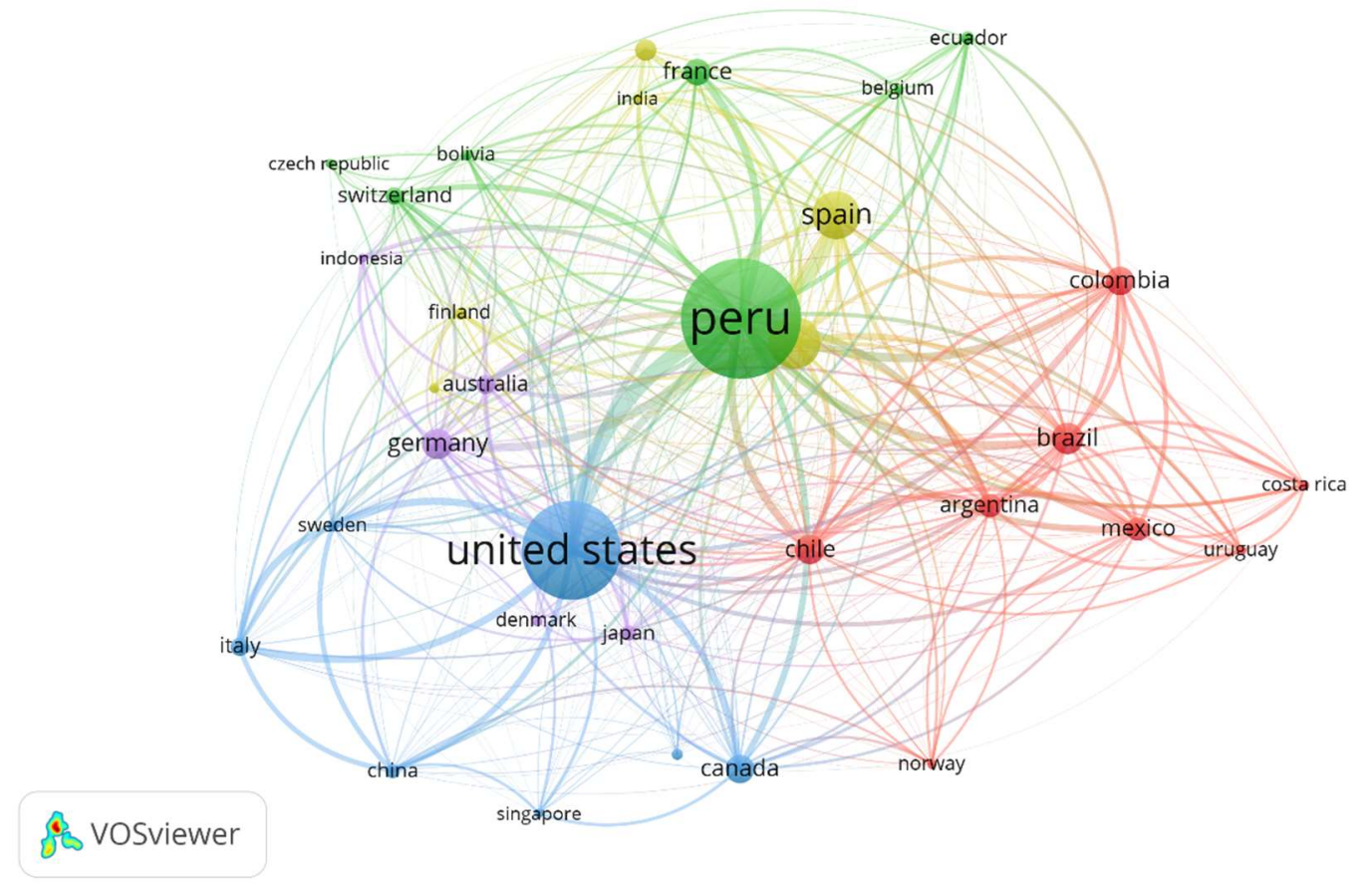

Source: own elaboration

\section{Co-citation per source}

Table 5 shows the level at which a scientific journal is cited together with another. Due to the large number of scientific sources, the minimum number of citations was increased to 40 , in order to avoid considering scientific journals from disciplines other than management and business topics. The most cited journal with the highest link strength is "Strategic Management Journal". It is evident that the journals with the highest linkage strength are those covering management and/or business topics.

Figure 5 shows the graphical representation of the co-citation network per source. It can be seen that the network is made up of two large groups. The group on the left, formed by a cluster of journals on topics such as ecology, science, nature, biodiversity, global development, etc. The group on the right contains two clusters that include several scientific journals on management, business and economics. 
Table 5. Co-citation per journals

\begin{tabular}{|c|c|c|c|}
\hline Rank & Source & Citations & $\begin{array}{l}\text { Total Link } \\
\text { Strength }\end{array}$ \\
\hline 1 & Strategic Management Journal & 167 & 5949 \\
\hline 2 & Journal Of Business Ethics & 153 & 2884 \\
\hline 3 & Science & 153 & 1858 \\
\hline 4 & $\begin{array}{c}\text { Journal Of International Business } \\
\text { Studies }\end{array}$ & 152 & 4101 \\
\hline 5 & World Development & 133 & 1208 \\
\hline 6 & Academy Of Management Review & 126 & 3584 \\
\hline 7 & Small Business Economics & 111 & 2994 \\
\hline 8 & Academy Of Management Journal & 106 & 3639 \\
\hline 9 & Journal Of Business Venturing & 95 & 3084 \\
\hline 10 & $\begin{array}{l}\text { Entrepreneurship Theory And } \\
\text { Practice }\end{array}$ & 87 & 2868 \\
\hline 11 & Journal Of Marketing & 80 & 2239 \\
\hline 12 & Journal Of Management & 71 & 2482 \\
\hline 13 & Nature & 71 & 920 \\
\hline 14 & Mol Ecol & 67 & 769 \\
\hline 15 & Energy Policy & 66 & 231 \\
\hline 16 & Journal Of Business Research & 66 & 1821 \\
\hline 17 & Ecology & 62 & 912 \\
\hline 18 & $\begin{array}{c}\text { Journal Of Small Business } \\
\text { Management }\end{array}$ & 62 & 2252 \\
\hline 19 & Plos One & 60 & 522 \\
\hline 20 & Harvard Business Review & 59 & 1239 \\
\hline 21 & Human Ecology & 56 & 506 \\
\hline 22 & Theor Appl Genet & 55 & 552 \\
\hline 23 & American Economic Review & 54 & 729 \\
\hline 24 & American Journal Of Primatology & 54 & 679 \\
\hline 25 & Sustainability & 53 & 396 \\
\hline 26 & American Anthropologist & 52 & 665 \\
\hline 27 & Journal Of Management Studies & 50 & 1729 \\
\hline 28 & Aids & 49 & 144 \\
\hline 29 & Conservation Biology & 48 & 485 \\
\hline 30 & International Journal Of Primatology & 48 & 685 \\
\hline 31 & Conserv Biol & 47 & 608 \\
\hline 32 & Ecological Economics & 47 & 555 \\
\hline 33 & Lancet & 47 & 221 \\
\hline 34 & Biodivers Conserv & 45 & 495 \\
\hline 35 & Biotropica & 40 & 643 \\
\hline 36 & Journal Of Financial Economics & 40 & 599 \\
\hline
\end{tabular}

Minimum number of citations per source: 40

Source: own elaboration 
Figure 5. Co-citation network per journals

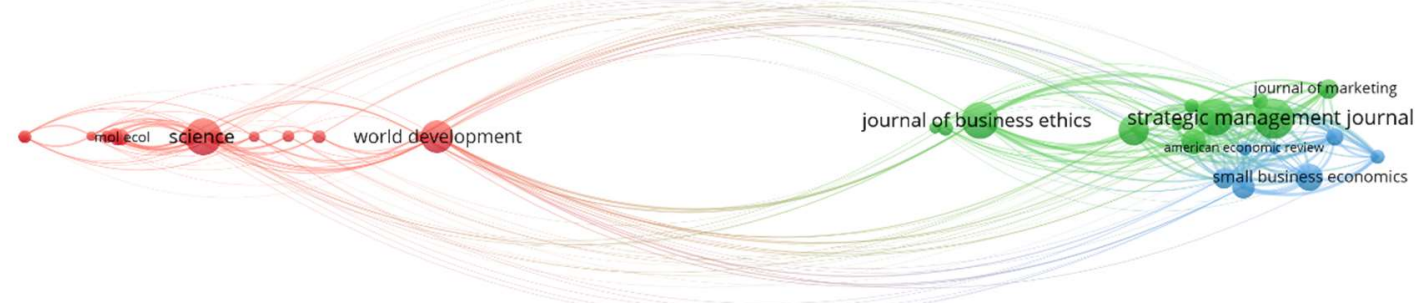

\section{A vosviewer}

Source: own elaboration

\section{Co-citation per author}

Table 6 shows the frequency in which authors are cited together. Mendo, J; Hofstede, G; and Young, K. R. are the most cited authors in the group, all exceeding 50 citations. Mendo, J. and Wolff, M. are the authors with the highest link strength by a significant amount. Although Hofstede, G. is one of the authors with the highest number of citations, he is one of the authors with the lowest level of link strength of the entire group. This may suggest that the author is usually cited on specific topics, which is why he is not usually cited with the other authors on the topics covered in this study.

Figure 6 shows the co-citation network per author. This suggests that researchers tend to be cited more frequently with authors researching similar topics. Noteworthy is the link between Mendo, J. and Wolff, M. which is, by a large margin, the strongest link in the entire network. This indicates that these two authors are often cited together when studying these topics. Also, it is important to highlight that the two authors have the same number of links, one to each other, one to Lambin, E.F. and one to Majluf, P. 
Table 6. Co-citation per author

\begin{tabular}{|c|c|c|c|}
\hline Rank & Author & Citations & Total Link Strength \\
\hline 1 & Mendo, J. & 61 & 738 \\
\hline 2 & Hofstede, G. & 60 & 48 \\
\hline 3 & Young, K.R. & 54 & 277 \\
\hline 4 & Wolff, M. & 48 & 729 \\
\hline 5 & Peres, C.A. & 44 & 309 \\
\hline 6 & Porter, M.E. & 32 & 133 \\
\hline 7 & Bebbington, A. & 30 & 63 \\
\hline 8 & Mittermeier, R.A. & 29 & 206 \\
\hline 9 & Sanchez, J. & 28 & 59 \\
\hline 10 & Weber, J.C. & 25 & 32 \\
\hline 11 & Thurik, R. & 25 & 61 \\
\hline 12 & Malhi, Y. & 25 & 78 \\
\hline 13 & Gentry, A.H. & 25 & 168 \\
\hline 14 & Terborgh, J. & 25 & 174 \\
\hline 15 & Coomes, O.T. & 24 & 104 \\
\hline 16 & Padoch, C. & 24 & 117 \\
\hline 17 & Lambin, E.F. & 24 & 169 \\
\hline 18 & Porter, M. & 23 & 21 \\
\hline 19 & Thorp, R. & 23 & 27 \\
\hline 20 & Kahhat, R. & 23 & 43 \\
\hline 21 & Cuervo-Cazurra, A. & 23 & 49 \\
\hline 22 & Kalliola, R. & 23 & 150 \\
\hline 23 & Di Fiore, A. & 22 & 212 \\
\hline 24 & Aquino, R. & 22 & 235 \\
\hline 25 & Mayer, E. & 21 & 58 \\
\hline 26 & Khanna, T. & 21 & 59 \\
\hline 27 & Shane, S. & 21 & 62 \\
\hline 28 & Brush, S.B. & 21 & 67 \\
\hline 29 & Barney, J.B. & 21 & 104 \\
\hline 30 & Heymann, E.W. & 21 & 109 \\
\hline 31 & Ortiz, O. & 21 & 117 \\
\hline 32 & Horton, D. & 21 & 300 \\
\hline 33 & Majluf, P. & 20 & 25 \\
\hline 34 & Audretsch, D.B. & 20 & 41 \\
\hline 35 & Caceres, C.F. & 20 & 51 \\
\hline 36 & Peterson, A.T. & 20 & 86 \\
\hline 37 & Parnell, J.A. & 20 & 110 \\
\hline 38 & Laurance, W.F. & 20 & 136 \\
\hline 39 & Thiele, G. & 20 & 240 \\
\hline 40 & Devaux, A. & 20 & 268 \\
\hline
\end{tabular}

Only the 40 authors with the highest level of citations are shown. 


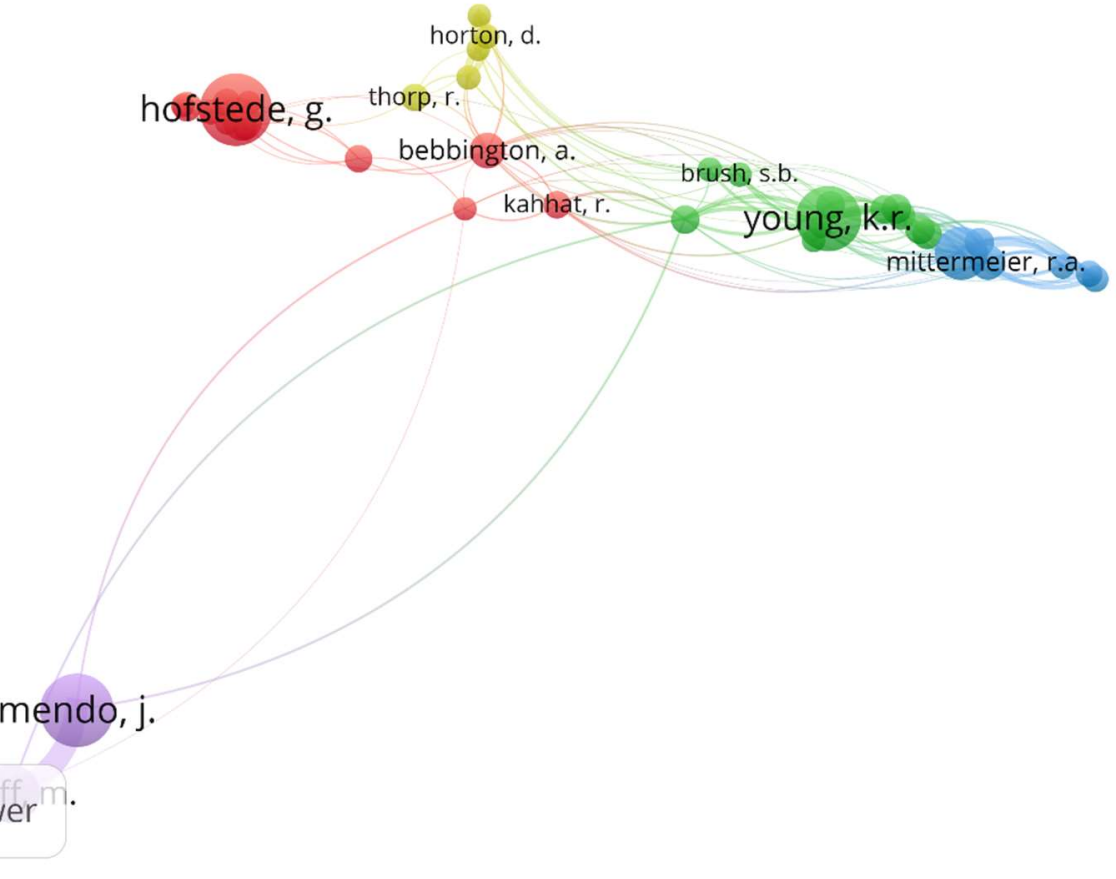

Source: own elaboration

\section{Conclusions}

This study allows us to observe the level of research existing on business in Peru. More than 900 studies on the subject were found in Scopus. The bibliometric analysis shows that Peru and the United States are the countries with the most documents and citations. Peru is also the most popular country for papers on these topics as it has the highest degree of co-authorship, citation, co-citation and bibliographic matching of all countries.

The journal with the highest citation and co-citation level is Strategic Management Journal. The most popular journals for business topics in Peru are those focused on management and/or business topics. The most cited authors are Mendo, J; Hofstede, G; and Young, K. R. In addition, Mendo, J. and Wolff, M. are the authors with the most joint papers. For future work, it is recommended to work with other databases following the same search criteria to analyze the effect of the database used.

\section{References}

Dubois, S. \& Walsh, I. (2017). The globalization of research highlighted through the research networks of management education institutions: the case of French business schools. M@n@gement, 20, 435-462. https://doi.org/10.3917/mana.205.0435 
Ferreira, J.J.M., Fernandes, C.I., Peris-Ortiz, M., \& Ratten, V. (2017). Female entrepreneurship: A co-citation analysis. International Journal of Entrepreneurship and Small Business, 31(2), 325-340.

Maia, J.L., \& Di Serio, L.C. (2017). Corporate governance and business strategy: of bibliometric mapping the scientific production in the field. Revista Gestao \& TecnologiaJournal of Management and Technology, 17(2), 160-185. https://doi.org/ 10.20397/21776652/2017.v17i2.1031

Moed, H. F. (2009). New developments in the use of citation analysis in research evaluation. Archivum Immunologiae et Therapiae Experimentalis, 57(1), 13-18. https://doi.org/10.1007/s00005-009-0001-5

Pineda-Escobar, M.A. \& Merigo, J.M. (2020). A bibliometric analysis of the Base/Bottom of the Pyramid research. Journal of Intelligent \& Fuzzy Systems, 38(5), 5537-5551

Van Eck, N. J., \& Waltman, L. (2010). Software survey: vosviewer, a computer program for bibliometric mapping. Scientometrics, 84(2), 523-538. Https://doi.org/10.1007/s11192-009-0146-3 